\section{"An April Hike"}

\section{By Ray Peterson}

R.R. 2, Tofield, Alberta

It was a bleak, raw Sunday in late April. Snow clouds shuttled heavily across the sky, and a skim of sludge and ice had spread over most of the pond. It was not a very promising afternoon for browsing in the woods but I fastened my jacket as snugly as possible and started out.

A crow flipped low over the fatbudded poplar trees, his unmusical voice sounding stout and cheerful. Surprisingly venturesome for such a glum day, a prairie gopher, or more formally, a Richardson Ground Squirrel whistled saucily. He dodged into his burrow as the dog with me bounced eagerly forward to meet the little animal's challenge.

My path arced a large, burn-out slough. Quacking vigorously in their springtime chorus that seems to tug at one's imagination, a pair of Mallard ducks rose from the far end. Nearby, in a bit of open water, a muskrat sat nibbling at cattail roots. The dog barked. Quickly, the rat uncurled from a round ball of mahogany-toned fur to a long, low-surfaced shape pushing easily through the water. It dived and I watched the slough intently. I expected to see the muskrat come to the top with a burst of shattered ice. But no! Mr. Rat surfaced without a ripple in another small oval of clear water. As though to prove that it wasn't an accident, he submerged again, swam under a long expanse of ice, and reappeared in a third open area.

I paused by a grove of birch trees. The wind, tugging at tattered streamers of loosened bark, was playing a strange rustling melody. Close by, a Robin scolded, and a Kildeer ran swiftly along a muddy ditch.

The dome of a large antpile caught my eve. Curiously, I poked a small stick into it. It was thawed out and so were its inhabitants. Myriads of rather sluggish insects clustered around the crater I had thoughtlessly made in their castle.

At the base of a side hill a couple of Sharp-tailed Grouse made a noisy take-off. Ack! Ack! from a willow thicket a pair of Magpies raised a din. The black and white robbers were losing no time in beginning housekeeping for another season.

As I neared home I edged close to a Chipping Sparrow and his neat, spry mate.

"Cheer up!" they seemed to be trying to tell me. "There're bright spots in the worst of days."

\section{Birds and Berries}

\author{
Mrs. Hilda Newton, Teacher \\ Lake Marguirite S.D.
}

Spring is with us once more and each day we welcome more joyous summer visitors, but we do not forget the brave little companions whose very presence cheered our dreary winter months. Snow Buntings we saw in hundreds - indeed summer fields seemed alive with "acres of them." During the snowy season many Bohemian Waxwings came in relays to feed on the showy but bitter ornamental crabs in my friend's garden. We were surprised to see so many - three flocks of around thirty in each, politely waiting their turn. We were also pleased to see a few flocks of Sharp-tailed Grouse. These are pitifully small. Surely we need a closed season.

I am now living south of Indian Head, in a beautiful valley where one is always finding nature's pleasant surprises. If anyone has ever seen our native High-bush Cranberry in bloom during early June and again when the graceful bushes are bowed down with large brilliant red fruit which one can smell even before finding it on a moist warm day. Then you need to be prepared for wading through marsh and over rotted stumps, for they like wet feet. No wonder birds love this unspoiled country!

Why do not more of our nature lovers plant some of these hardy native fruit-bearing shrubs around home grounds to provide feed and shelter for our trusting feathered friends? 